\section{2. ro: (Receiving organization) \\ Distribution}

5. Proj./Prog./Dept./Div.:

Spent Nuclear Fuel Project

8. Originator Remarks:

For approval and distribution.

11. Receiver Renarks:

11A. Design Basel ine Document?

[ ] res
3. From: (originating Organization) SNF Characterization Project/ 2T720

6. Design Authority/ Design Agent/Cog. Engr.:

D.P. Maassen
4. Related EDT No.:

7. Purchase Order No.:

$N / A$

9. Equip./Component Ho.:

N/A

10. System/Bldg./Facility: $\mathrm{K}$ Basins $/ 100-\mathrm{K}$

12. Major Assm. Dwg. No.: N/A .

13. Permit/Permit Application No.: N./A...

14. Required Response Date: $\mathrm{N} / \mathrm{A}$

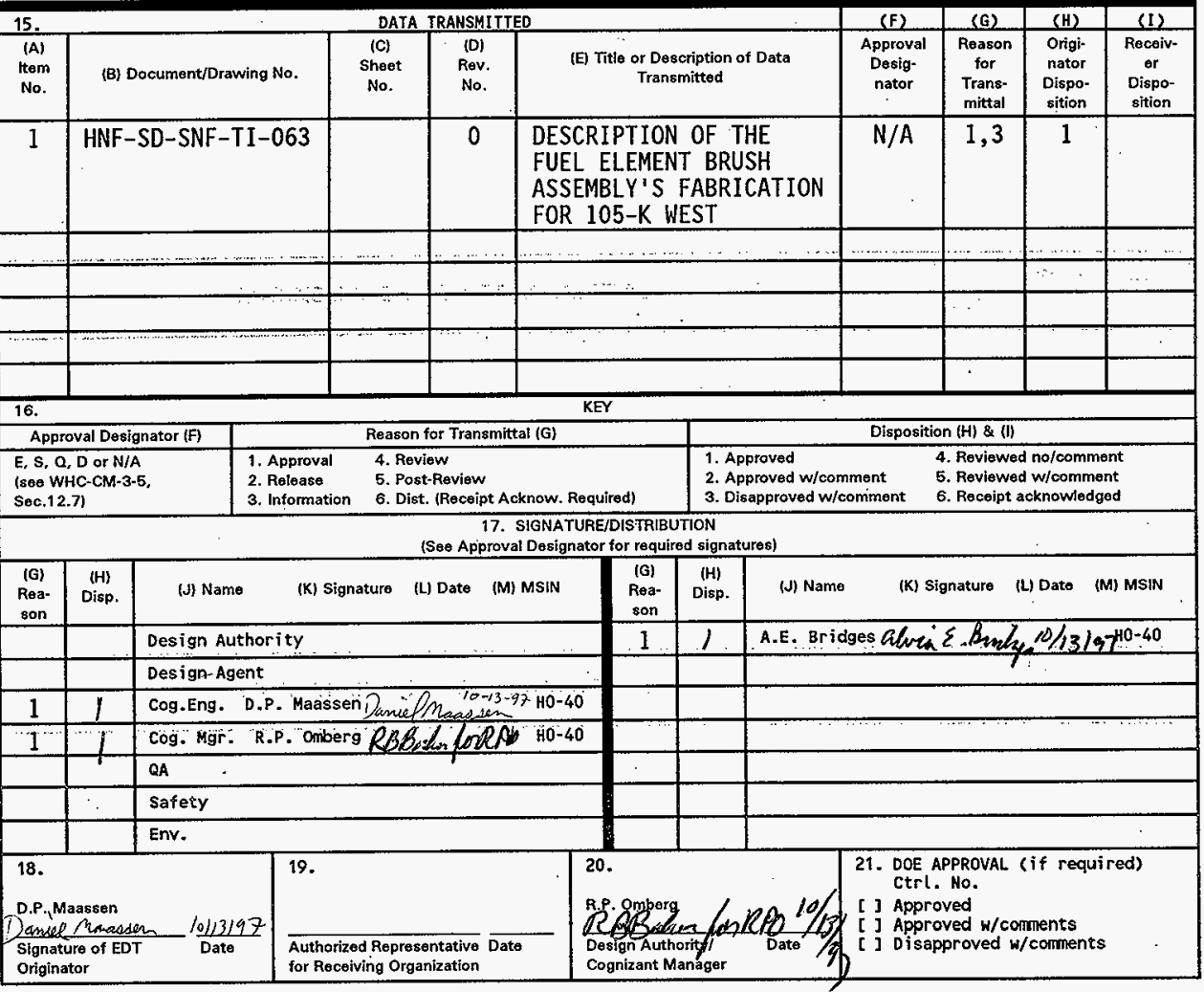




\title{
DESCRIPTION OF THE FUEL ELEMENT BRUSH ASSEMBLY'S FABRICATION FOR 105-K WEST
}

\author{
D. P. Maassen
}

Duke Engineering \& Services Hanford, Inc., Richland, WA 99352

U.S. Department of Energy Contract DE-AC06-96RL13200

$\begin{array}{lll}\text { EDT/ECN: } & 620795 & \text { UC: } 2070 \\ \text { Org Code: } & 2 \text { TT20 } & \text { Charge Code: } \text { LB030 } \\ \text { B\&R Code: } & \text { EW7040000 } & \text { Tota7 Pages: } 29\end{array}$

Key Words: 105-K West, Fuel Element Brush Assembly, Fabrication, Design

Abstract: This report is a description of the process to redesign and fabricate, as well as, describe the features of the Fuel Element Brush Assembly used in the 105-K West Basin. This narrative description will identify problems that occurred during the redesigning and fabrication of the 105-K West Basin Fuel Element Brush Assembly and specificaTly addresses their solutions.

IRADEMARK DISCLAIMER. Reference herein to any specific comercial product, process; or service by trade name, trademark, manufacturer, or otherwise, does not necessarily constitute or imply its endorsement, recommendation, or favoring by the United States Government or any agency thereof or its contractors or subcontractors.

Printed in the United States of America. To obtain copies of this document, contact: Document Control Services, P.O. Box 950, Mailstop H6-08, Richland WA 99352, Phone (509) 372-2420; Fax (509) 376-4989.

$\frac{\text { Ahrotien Jillexpham } 10-14-97}{\text { Release approval }}$

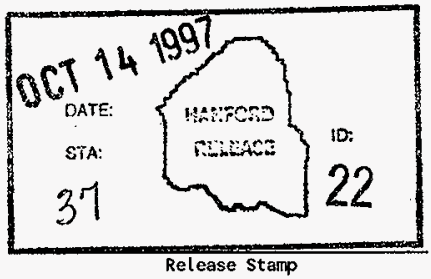


HNF-SD-SNF-TI-063, Rev. 0

DESCRIPTION OF THE FUEL ELEMENT BRUSH ASSEMBLY'S

FABRICATION FOR 105-K WEST

D. P. Maassen

October 1997 
HNF-SD-SNF-TI-063, Rev. 0

\section{CONTENTS}

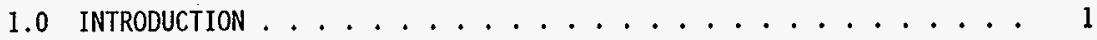

2.0 RESEARCHING THE OLd DESIGN ................ 3

3.0 REDESIGNING THE FUEL ELEMENT BRUSH ASSEMBLY . . . . . . . . 7

4.0 TESTING AND MODIFYING THE FUEL ELEMENT BRUSH ASSEMBLY . . . . . . 11

5.0 FIELD USE AND MODIFICATIONS . . . . . . . . . 15

5.1 MODIFYING THE FUEL ELEMENT BRUSH ASSEMBLY ......... 15

5.2 FIELD USE . . . . . . . . . . . . . . . 18

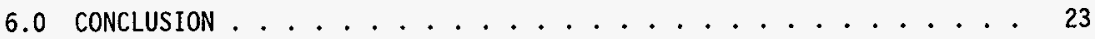

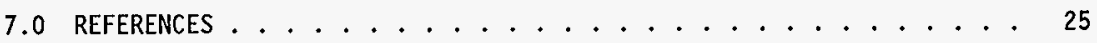


HNF-SD-SNF-TI-063, Rev. 0

\section{LIST OF FIGURES}

1. The First Sketch of the 105-K East Basin Fuel Element Brush Assembly (Conceptual Design) ............ 4

2. Pictures of the Actual Fuel Element Brush Assembly Used in 105-K East ............... 5

3. 105-K West Basin Sketch (based on the Drawing H-1-21072, Rev. 0) of the Specific Area where the Sludge Adherence Testing will occur.................. 8

4. Sketch of the 105-K West Basin Fuel Element Brush Assembly Before Functional Testing ............. 9

5. Picture of the 305 Building Engineering Testing Laboratory's Cold Test Facility where the Functional Test of the Fuel Element Brush Assembly Occurred ............... 12

6. K West Fuel Element Brush Assembly After Fabrication was Completed at the 305 Building Engineering Testing Laboratory . . . . 14

7. Part of the Drawing (H-1-44923, Rev. O) of the Canister Storage Racks ................. 16

8. Modifications to the Fuel Element Brush Assembly . . . . . . . . . 17

9. Sketch of the Final Fuel Element Brush Assembly Used in 105-K West ............... 19

10. The Final Fuel Element Brush Assembly Used in 105-K West . . . . . . 20 
HNF-SD-SNF-TI-063, Rev. 0

\section{DESCRIPTION OF THE FUEL ELEMENT BRUSH ASSEMBLY'S FABRICATION FOR 105-K WEST}

\subsection{INTRODUCTION}

The Spent Nuclear Fuel Project (SNFP) is proceeding to remove al1 the fuel from the 105-K East (KE) and 105-K West (KW) Basins into dry storage at the Canister Storage Building (CSB) in the 200 East Area. One of the many steps in doing this process is fuel characterization. Fuel characterization was performed in the KE Basin and is on-going in the KW Basin. A crucial step in the characterization of the fuel is identifying the adhesiveness of sludge on the fuel elements. The testing of sludge adhesiveness was first started in the KE Basin and showed that the sludge could be removed by a method of brushing using a Fuel Element Brush Assembly (FEBA) (Bergmann 1996). The test consisted of a known instrument (the FEBA) that was used to compare the adhesiveness of different types of sludges found on the fuel elements. Subsequently, it was necessary to perform this process on the KW Basin fuel. The FEBA used in the KE Basin was contaminated beyond acceptable levels for removal; therefore, a new FEBA was fabricated for the KW Basin. Also, the FEBA had to be redesigned for the KW Basin because the FEBA that was used in the KE Basin was designed for use on top of a storage rack inside the basin. There were no storage racks of this type available in the specific area of the $\mathrm{KW}$ Basin where the fuel was to be brushed.

The new FEBA used the same stainless steel wire brushes as the KE FEBA: (1) to clean the outside surface of an outer $N$ Reactor fuel element and (2) to determine the adhesiveness of KW fuel elements' sludge coatings. The project was started on December 16, 1996 and completed on January 23, 1997. The FEBA was fabricated at the 305 Building Engineering Testing Laboratory (ETL) in the 300 Area on the Hanford Site. The design was developed in conjunction with the ETL engineers and the SNF Characterization Project (SNFCP) engineers.

Only the outer fuel elements were tested. The cost of fabricating a FEBA that could clean inner fuel elements was not cost effective for the data it would collect. Both the inner and outer fuel elements were made from the same materials and subjected to the same environments. The visual examinations of the fuel (Pitner 1997) proved that the different types of sludge that were formed on the inner fuel elements were also on the outer fuel elements. The only difference between the two fuel elements were their shapes. Therefore, the KW FEBA, as well as the KE FEBA, was designed to accommodate only an outer fuel element. 
HNF-SD-SNF-TI-063, Rev. 0

This page intentionally left blank. 


$$
\text { HNF-SD-SNF-TI-063, Rev, } 0
$$

\subsection{RESEARCHING THE OLD DESIGN}

The first step in fabricating a new FEBA was to review the design of the FEBA used in the KE Basin. During the design review, it was discovered that there was not an accurate sketch of the FEBA; however, a preliminary sketch was found. This sketch, shown in Figure 1, is the basic conceptual design of the FEBA used in the KE Basin.

The design review did lead to some helpful details of the FEBAs fabrication and design. The best information about the KE FEBAs design was discovered by communicating with the two engineers (an ETL engineer, and a Transportation and Packaging engineer) who designed and built the KE FEBA. They remembered a good portion of the device's fabrication and gave some useful suggestions for the construction of a new FEBA. Additionally, pictures (see Figure 2), obtained from a video tape recording of the use of the FEBA in the KE Basin, gave a good general image of the first FEBAs design. Additional information about the FEBA was obtained by talking to the SNFCP engineering technicians who used the device in the KE Basin. They had a general idea of the FEBA and gave good insight on how it worked during the brushing activity in the KE Basin.

The conceptual design of the KE Basin FEBA is shown in Figure 1. The basic design for the KE Basin FEBA was described as follows: One-inch long stainless steel wire brushes were installed on the inside of a 4-inch diameter, schedule 40, stainless steel pipe. This pipe was sealed at the bottom by welding on a plate. Additionally, a stainless steel rod (1/4 inch diameter) was welded to the bottom plate and centered in the pipe. Holes were cut into the plate between the center rod and pipe to allow water to pass through the bottom end of the pipe. Quarter-inch long stainless steel wire brushes were attached to the center rod. The 1-inch and 1/4-inch wire brushes were selected through a trial and error process of testing many different length bristles. The brushes on the center rod, designed to brush the inside of the element, were removed before the experiment began in the KE Basin. They were found to be unnecessary as there was no way to view the removal of sludge coatings from inside the fuel element with the underwater camera. All of the necessary data acquired from the KE testing was obtained by brushing the outer surface of the outer fuel element. Additionally, there was a concern that the fuel element would get stuck inside the FEBA because of the friction between the two sets of brushes and the fuel element. The KE FEBAs cylinder was attached to a stainless steel heavy base with a flange that added a great deal of weight. Hooks were insta7led to the bottom plate to keep it on top of a canister storage rack and prevent the FEBA from rotating. The KE FEBA was very stable and there was never any indication that it would tip over during testing in the basin. The friction between the FEBA and fuel element was good enough to remove the sludge and the fuel element was easily removed from the FEBA (Bergmann 1996). 
HNF-SD-SNF-TI-063, Rev. 0

Figure 1. The First Sketch of the 105-K East Bas in Fuel Element Brush Assembly (Conceptual Design). (All units are in inches untess otherwise specified.)
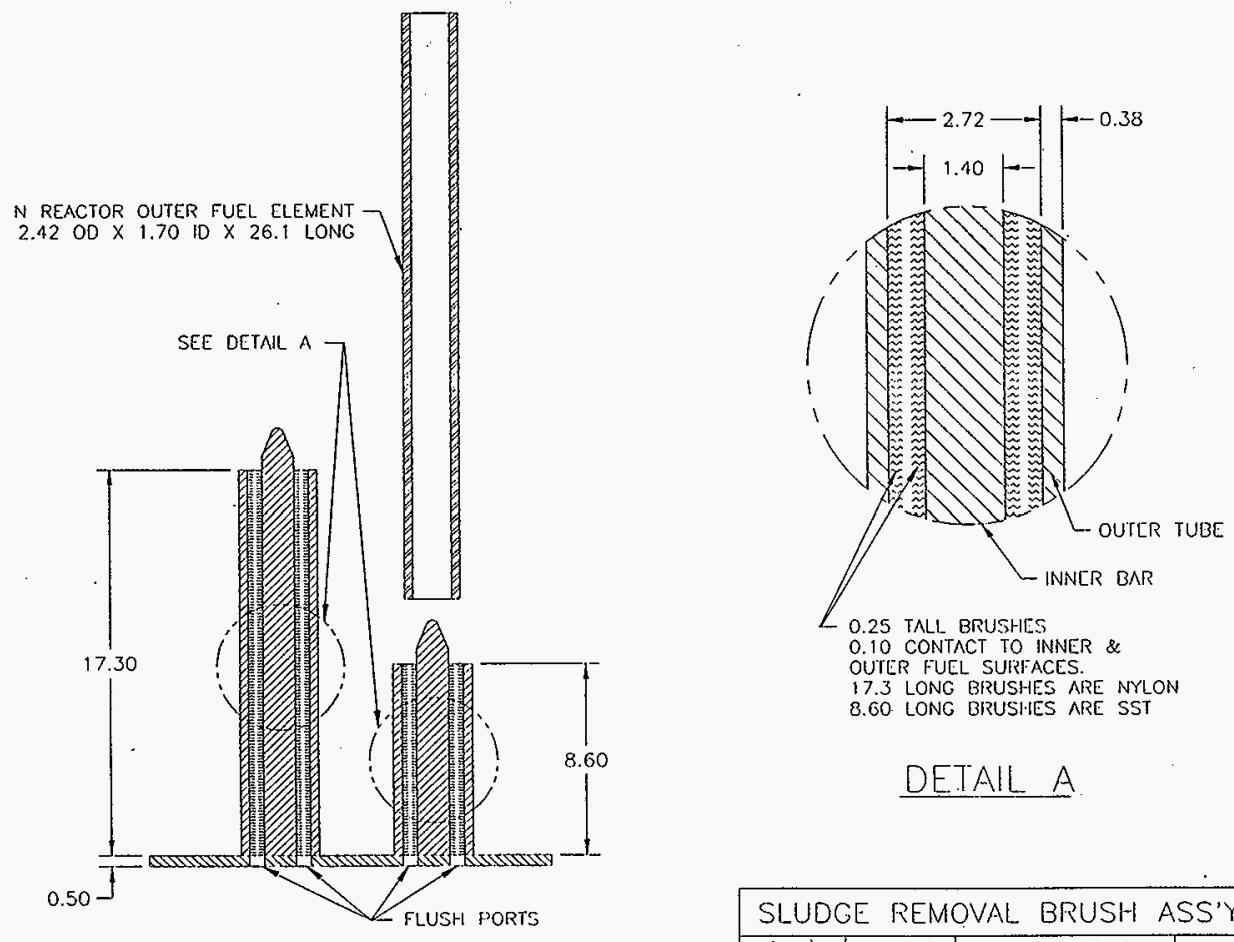

\begin{tabular}{|l|l|l|l}
\hline SLUDGE REMOVAL BRUSH ASS'Y & 0 \\
\hline
\end{tabular} 
Figure 2. Pictures of the Actual Fuel Element Brush Assembly Used in 105-K East.
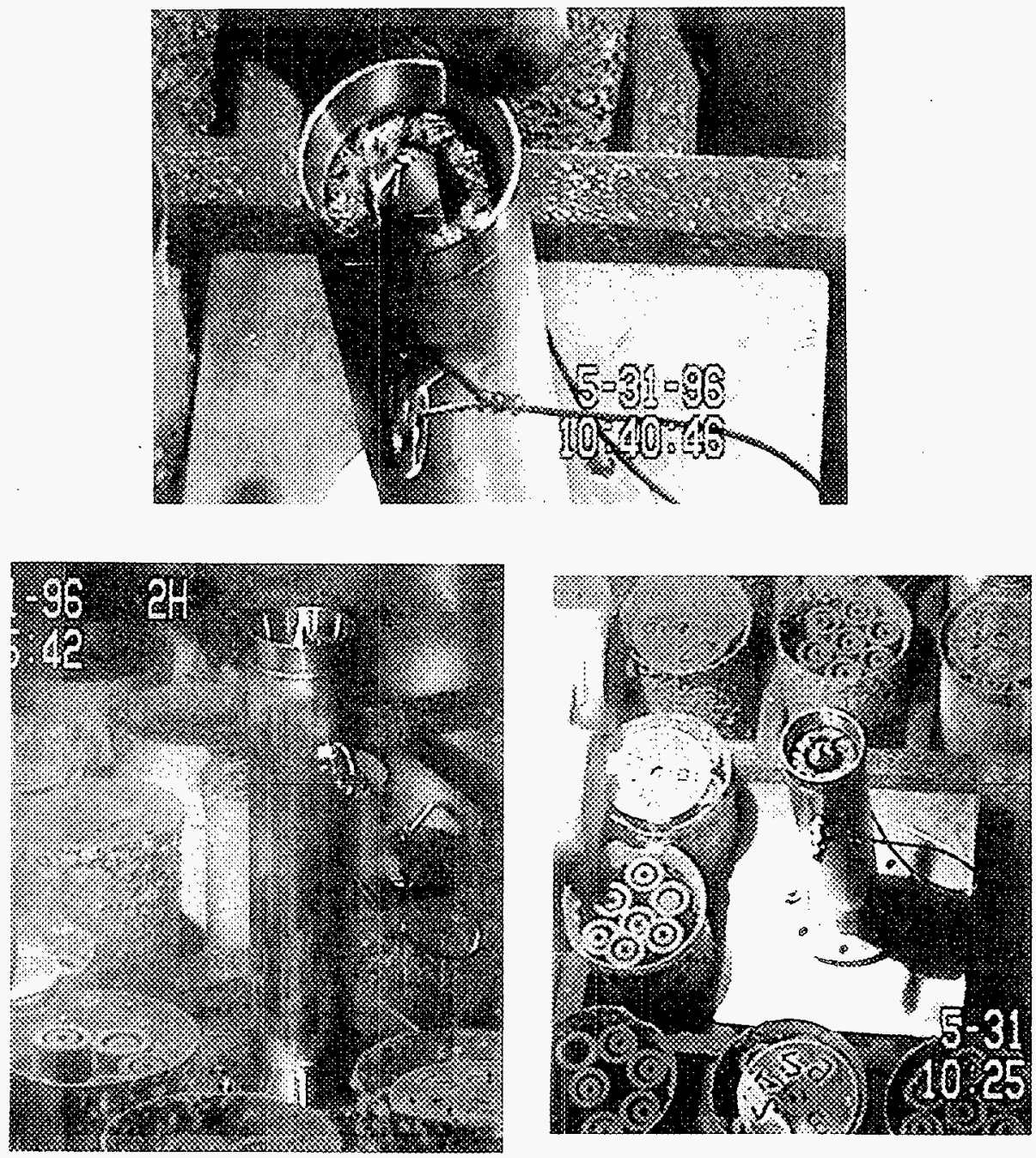
HNF-SD-SNF-TI-063, Rev. 0

This page intentionally left blank. 


\subsection{REDESIGNING THE FUEL ELEMENT BRUSH ASSEMBLY}

The next step in fabricating a new FEBA was to redesign the FEBA for the $\mathrm{KW}$ Basin. This redesign was necessary because, while the KE and KW Basins are similar in structure, they differ in their operating procedures. In the KE Basin, all the fuel canisters are uncovered, releasing radioactive contaminants to the water. Brushing of the fuel was allowed anywhere in the KE Basin, giving the test engineer the freedom of placing the FEBA on top of the nearest canister rack. In contrast, the $\mathrm{KW}$ Basin contains the fuel in covered canisters, reducing the amount of radioactive contaminants in the water and, consequently, the radiation environment inside the basin. In order to maintain this low contamination environment, there were only two places the FEBA could be used in the KW Basin (PS-304-B3 1996): (1) the transfer channel and (2) the South Loadout Pit. These two locations combine to make a shipping cask transport pit in the Southwest corner of the KW Basin. After examining the KW Basin drawing, "Structural Concrete Sections and Details at Elevation $0^{\prime \prime}$ " of Storage and Transfer Area," $\mathrm{H}-1-21072$, Rev. 0 (a sketch of the testing location that was created from the drawing is shown in Figure 3 ), the best location for the FEBA was determined to be in the transfer channe1. The additional depth of the South Loadout Pit would have created a problem with the outer fuel element handling tool (H-1-80544, Rev. 1) which was used to insert an element into the FEBA. The fuel element handling tool was designed to operate in the transfer channe 1 or the basin proper. However, the South and North Loadout Pits are 5 feet deeper than the transfer channel.

A specific location was chosen to place the FEBA on the floor of the transfer channe] between the decapping station and canister racks by a test engineer at the KW Basin. Initial information indicated that this area was cleared of debris or obstructions, and the FEBA could be placed there. The sketch of this area is shown in Figure 3. The area had a dimensional space of 2 feet 1 ong by 2 feet wide. The specific dimensions of 20 inches long by 20 inches wide were given to the SNFCP design engineer as an acceptable area for the FEBA to occupy. This reduced area was used as a precautionary measure to make sure the FEBA would fit on the transfer channel's floor.

Placement of the KW FEBA on the floor instead of on top of a canister rack resulted in the following differences: (1) there were no hooks underneath the KW FEBAs baseplate (1ike there was on the KE FEBA) and (2) a stainless steel plate (20 inches $\times 20$ inches $\times 1$ inch) was used for the base. A sketch of this second FEBA is shown in Figure 4. The hooks on the KE FEBA prevented it from rotating or lifting from the canister storage rack. To prevent this from occurring with the KW FEBA, the heavy stainless steel base was added. In total, the KW FEBA weighed 137 pounds. Additional design changes included: (1) elimination of the unnecessary center brush and rod; (2) addition of an inclined ring at the top to act as a funnel for inserting a fuel element; and (3) addition of a 0.5-inch diameter stainless steel rod to the bottom of the FEBA to reduce the possibility of a broken fuel element falling to the basin floor. All of these modifications helped transform the KW FEBA into a floor model, satisfying the original design requirements of the tool. 
Figure 3. 105-K West Basin Sketch (based on the Drawing H-1-21072, Rev. 0) of the Specific Area where the Sludge Adherence Testing will occur (all units are in inches unless otherwise specified).

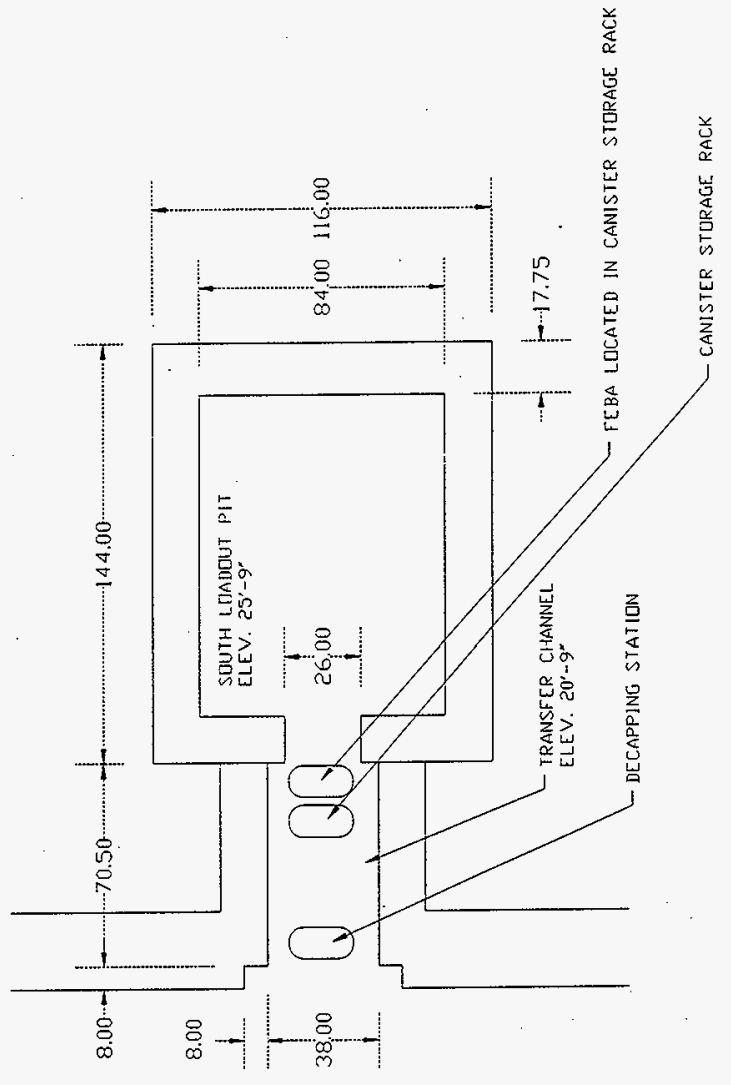

$z$
$\frac{2}{4}$
4
1
3
3 
Figure 4. Sketch of the 105-K West Bas in Fuel Element Brush Assembly Before Functional Testing.

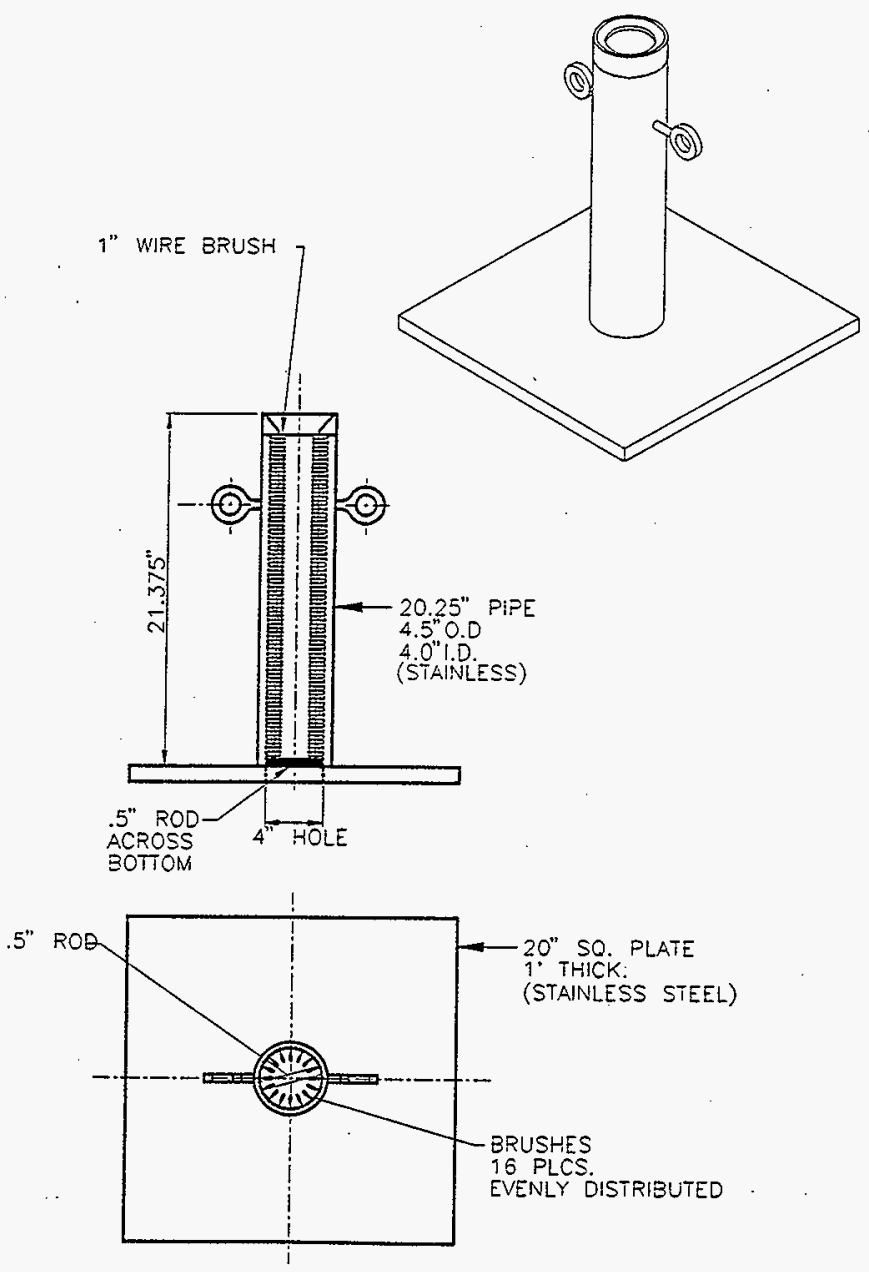


HNF-SD-SNF-TI-063, Rev. 0

This page intentionally left blank. 
HNF-SD-SNF-TI-063, Rev. 0

\subsection{TESTING AND MODIFYING THE FUEL ELEMENT BRUSH ASSEMBLY}

The FEBA was functionally tested in the Cold Test Facility's pool at the 305 Building ETL and the results were recorded on videotape (Videotape 1997). A picture of the pool is shown in Figure 5 . The only dimensional-type of dummy fuel element that was available for testing had an outside diameter of 2.385 inches and weighed 21 pounds. This is in contrast to the "real" outer fuel element's outside diameter of 2.400 inches and weight of approximately 40 pounds. The difference in the outside diameter was accounted for by ensuring the dummy fuel element was easier to remove from the FEBA than if a "real" fuel element was used. This criteria was tested by pushing and pulling the dummy fuel element in and out of the FEBA.

The acceptance criteria for this functional test were: (1) the FEBA had to stay on the pool's floor with no rotation while the dummy fuel element was being inserted and removed from it and (2) the resistance between the brushes and the dummy fuel element had to be the maximum that will still allow the dummy fuel element to be removed easily by one person.

The test was successful in identifying some problems with the FEBA. The first problem was the FEBA slid around on the pool's floor. Additionally, the FEBA was periodically pulled approximately 6 inches off the floor. The third problem was it took two technicians to pull the dummy fuel element out of the FEBA. The operator should feel some resistance while removing the fuel element but should not struggle while removing it from the FEBA.

The main causes for these problems were: (1) .lack of friction between the bottom plate and the floor of the pool; (2) lack of weight of the FEBA; and (3) too much friction between the stainless steel brushes and the dummy fuel element. These problems were thought to be more severe because a "real" fuel element would be even more difficult to remove. The solution to these problems included a combination of the methods described below: (1) add more weight to the FEBA; (2) increase the friction between the floor and the FEBA by using a different material with a higher friction coefficient and/or increase the surface area between the FEBAs base plate and the floor; and (3) decrease the amount of friction between the fuel element and the FEBAs brushes without compromising the ability of the FEBA to clean fuel elements.

The first modification to the FEBA was to weld on two L-shaped stainless steel strips ( $1 / 2$ inch high $\times 1 / 2$ inch wide $\times 17$ inches $l o n g)$ onto the bottom of the FEBAs plate. These new legs gave a greater friction force between the FEBA and the floor of the basin because: (1) the entire weight of the FEBA was supported by the rough edges of the stainless steel strips and (2) these rough edges would catch the rough uneven surface of the floor, increasing the amount of force it would take to rotate the FEBA. Also, this modification provided the added benefit of creating a space for water and sludge to escape through the bottom of the FEBA. Most of the sludge will be exiting through the open spaces of the brushes at the top of the FEBA. However, it still seemed necessary to have an exit at the bottom of the FEBA for any settling sludge. 
Figure 5. Picture of the 305 Building Engineering Testing Laboratory's Cold Test Facility where the Functional Test of the Fuel Element Brush Assembly Occurred.

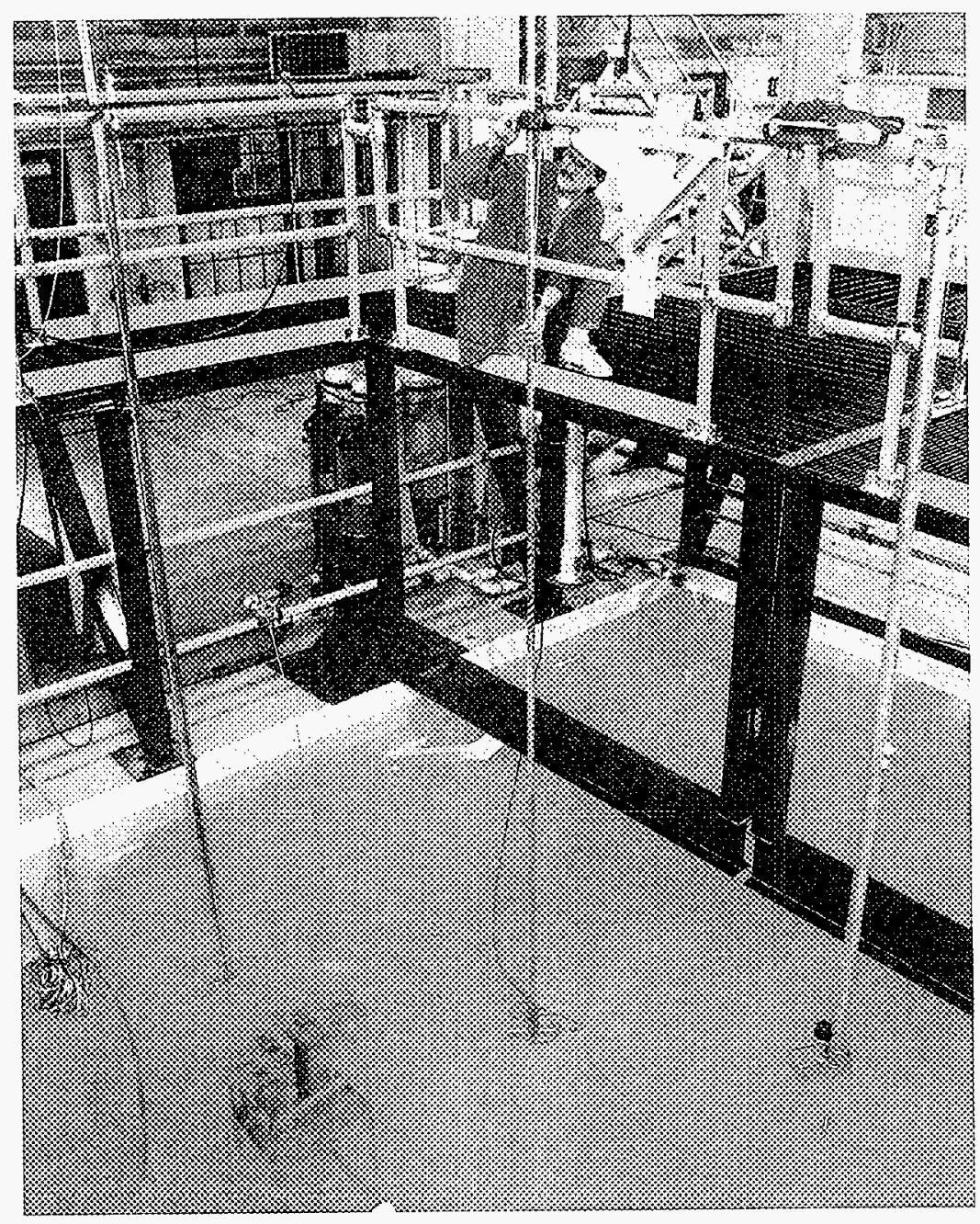


The next modification was to reduce the frictional force between the brushes and the dummy fuel element. The goal was to reduce the length of the wire brushes by $1 / 16$ inch. This was accomplished by using three Merit 80 Grit flapper wheels with diameters of 2.11 inches. After the grinding of the wire brushes, the dummy fuel element still seemed hard to remove from the FEBA; therefore, the following actions were taken: (1) a 3-inch-outside-diameter pipe was used to mash down the wire brushes and (2) an 1/8 inch was melted off the brushes in the lower 8 inches of the FEBA. The melted ends of the brush formed into ball-1ike end points. The usefulness of the ball-like end point bristles are not known compared to the wire bristles that were not melted.

After all the modifications, the final diameter of the space created between the top portion of the FEBAs brushes was 2-1/8 inches compared to the original space of 2 inches (a total of $1 / 16$ inch was taken off from the original brushes with an additional $1 / 8$ inch taken off of the lower 8 inches of the brushes). The functional test was repeated on the modified FEBA and the results were: (1) it was much easier to pull out the dummy fuel element from the FEBA; (2) the FEBA never left the pool's floor; and (3) the FEBA did not slide on the pool's floor. These results indicated that the frictional force increased between the FEBAs bottom plate and the pool's floor, while the frictional force decreased between the fuel element and wire brushes. The FEBA, shown in Figure 6, was shipped to the KW Basin for use in the sludge adhesiveness testing. 
Figure 6. K West Fuel Element Brush Assembly After Fabrication was Completed at the 305 Building Engineering Testing Laboratory.

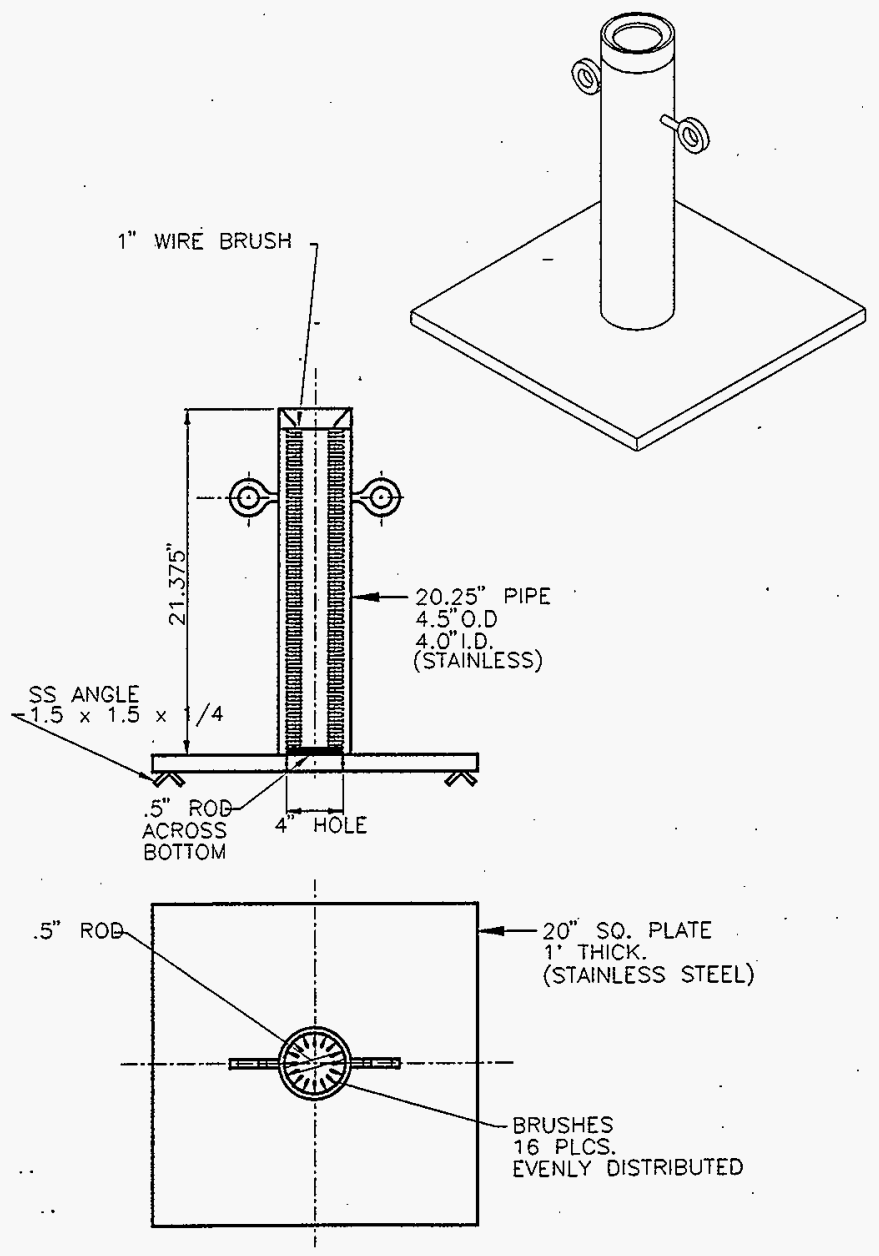




\subsection{FIELD USE AND MODIFICATIONS}

At the $\mathrm{KW} \mathrm{Basin}$, it was discovered that the FEBA could not be placed on the floor of the transfer channel (between the decapping station and the canister storage racks) because there were objects in the way not accounted for on the transfer channel drawings. This was contrary to the information that was given previously. This error may have occurred because there was no walk down performed in the transfer channel or there was a misunderstanding as to the physical requirements of the FEBA. An elevator was located in the area the FEBA was to occupy, preventing it from being placed there. The only logical solution was to modify the FEBA to fit inside a canister storage rack located further West in the transfer channel.

\subsection{MODIFYING THE FUEL ELEMENT BRUSH ASSEMBLY}

Dimensions of the canister storage racks were taken from the Drawing H-1-44923, Rev. 0, (part of the drawing is shown in Figure 7). Using these measurements, the FEBA was redesigned from a floor model to one that fits inside a canister storage rack while retaining the FEBAs weight. A preliminary sketch of the redesigned FEBA is shown in Figure 8. The steps needed to modify the FEBA for this redesign were: (1) remove 5 inches of stainless steel plate on two sides (along with the two L-shaped strips); (2) cut each corner at a 45-degree angle, removing four triangularshaped pieces; (3) weld the four triangles to the bottom part of the plate; and (4) weld the two stainless steel plate sides onto the cylinder of the FEBA.

The SNFCP group needed the FEBA as soon as possible. The fuel sampling campaign had a7ready started and the SNFCP group was decapping canisters that had candidate fuel elements for brushing. The quicker the SNFCP group received and installed the modified FEBA in the KW Basin, the more time there would be to test fuel elements:

After the job was started, it was known that the planned modifications to the FEBA would be completed in 3 business days. The critical path of the FEBA project compared to the fuel sampling campaign was examined and it was determined that the FEBA needed to be completed within the next business day. It was determined the FEBAs completion schedule was not feasible and needed to be accelerated. The modifications were re-engineered to decrease the amount of time the FEBA was inoperable.

The reasons for the extended schedule were examined to see if the project could be finished in a more efficient manner. One difficulty was the bottom plate was being cut by a band saw which was taking a long time (the cutting of the FEBAs base plate ultimately took 12 hours). Since there was not a faster method of cutting the bottom $\mathrm{plate}$ in the $100-\mathrm{K}$ Area, this task was continued. Another difficulty was scheduling a welder. The earliest a welder could be available was in three business days. This set back could have significantly extended the restructuring schedule of the FEBA unless an alternative method was used to attach the pieces to the FEBA. 
Figure 7. Part of the Drawing (H-1-44923, Rev. O)

of the Canister Storage Racks. (A11 units are

in inches unless otherwise specified.)

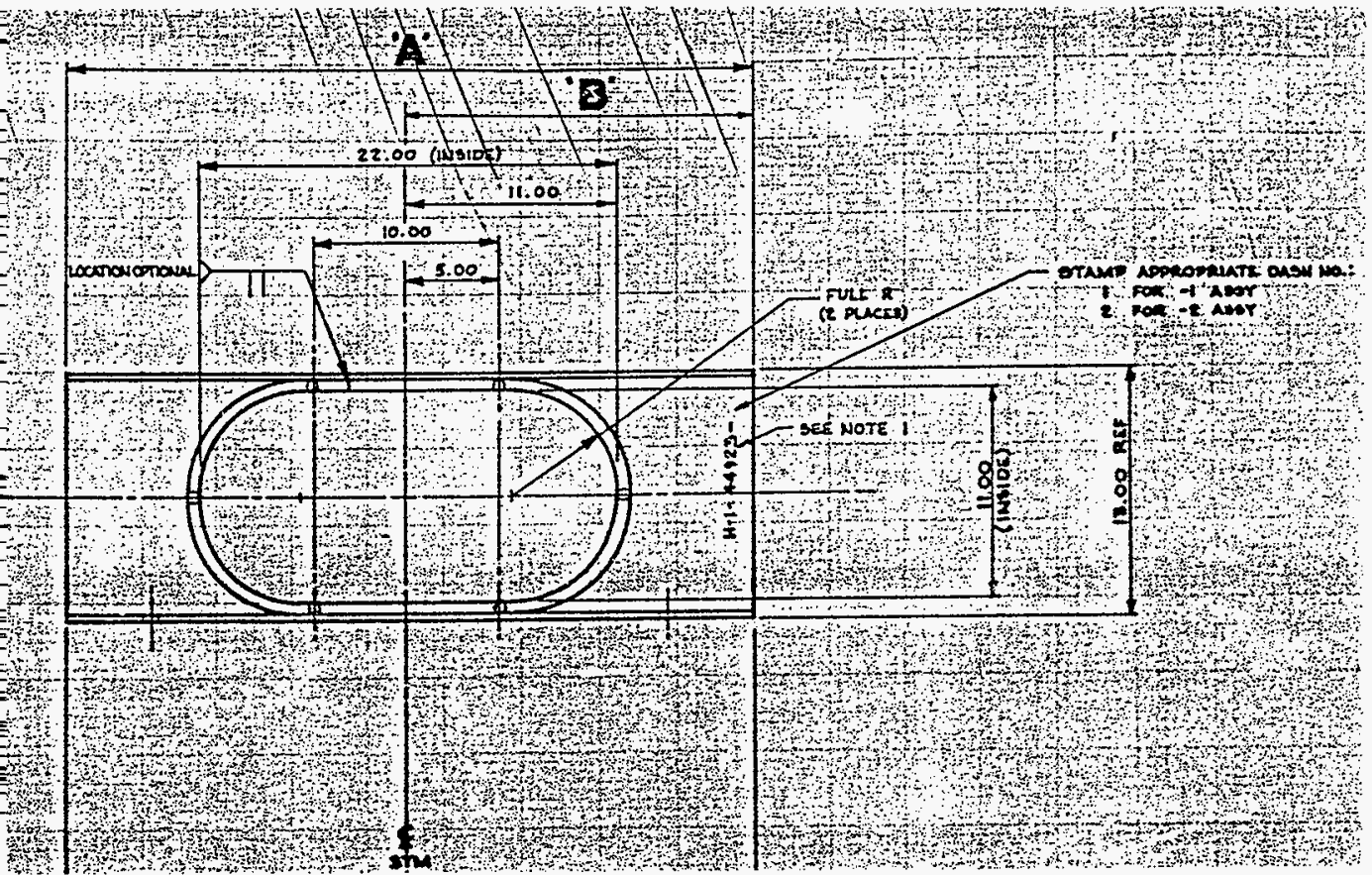


Figure 8. Modifications to the Fuel Element Brush Assembly. (A11 units are in inches unless otherwise specified.)

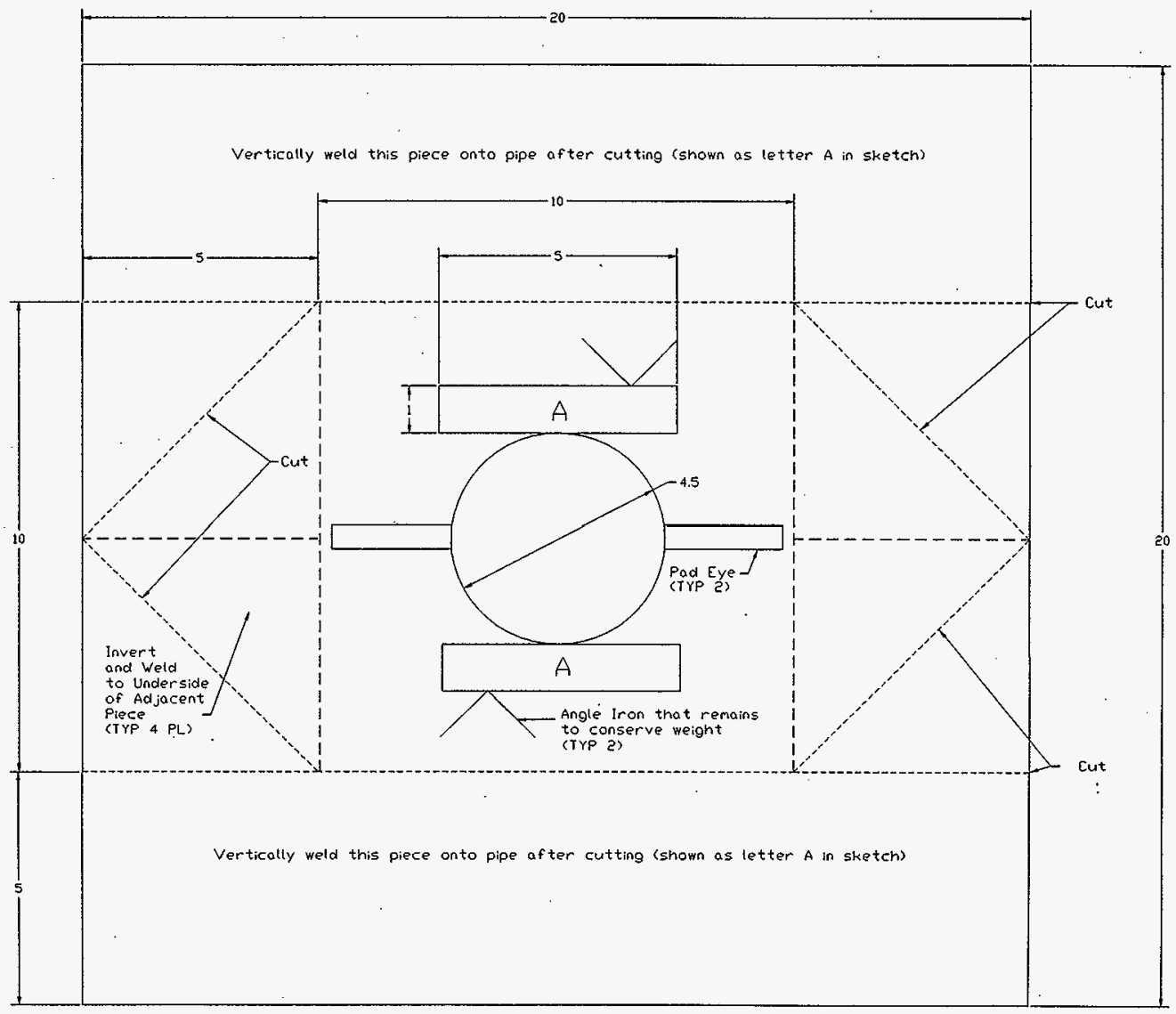




$$
\text { HNF-SD-SNF-TI-063, Rev. } 0
$$

A solution to completing the FEBA within the next business day was proposed. An alternative to welding the cut parts would be to mechanically attach them by screws. This could be accomplished by millwrights in the 100-K Area. This solution would get the FEBA assembled and in the water for use in the time required. Another idea that would save time was to attach only two of the triangle pieces. Using only two of the triangular pieces for the base of the FEBA would adequately keep it stable.

After all of the cuts were completed to the FEBAs base plate, the two triangular pieces were attached by four 2-inch long stainless steel screws. The shanks of the screws were then grounded down until they were smooth with the top surface of the bottom plate. This removed a potential safety hazard.

During this time of modification to the FEBA, two blocks were designed to replace the lost weight of the two plate sides (approximately 57 pounds) because these $p 1$ ates could not be readily attached by mechanical means. After some discussion with an engineer and the technicians at the 305 Building ETL, it was determined to attach the two stainless steel blocks to the top of the FEBAs bottom $p$ late using screws. The dimensions of the b7ocks were determined by reviewing the modified drawings (see Figure 8 ) for any open spaces on the FEBAs top plate to place the stainless steel blocks. Upon completed fabrication of the two stainless steel blocks, they. were delivered to the 100-K Area for attachment.

During this time, a welder became available; therefore, the FEBA was taken to the 200 Area to have the stainless steel blocks welded on instead of mechanically attached. Welding was a less time consuming and more reliable method of attaching the stainless steel blocks onto the top of the FEBAs base plate. After the blocks were welded on, the FEBAs modifications were completed.

The FEBA was inspected; it was a little more unstable than it was before as its base supports had been reduced. The redesign and modifications were determined acceptable. A sketch and pictures of the final as-modified FEBA are shown in Figures 9 and 10 . This sketch is accurate enough to be used for the next time a FEBA needs to be fabricated for the KW Basin.

\subsection{FIELD USE}

The FEBA was placed in the center of one of the transfer channel's canister storage racks that had no obstructions. The storage rack itself surrounded most of the FEBA except for the top 2 inches and had about 1 inch of clearance on each side. One advantage of placing the FEBA inside the canister storage rack was the rack kept it from falling over or moving around. The FEBA seemed stable with no swaying inside the rack.

The first element was selected to be brushed and brought to the FEBA by an operator. The operator inserted the fuel element about 6 inches into the FEBA. There was no motion from the FEBA that was detected. The fuel element was then inserted another 3 inches with no motion from the FEBA. The fuel element was then removed and the FEBA swayed slightly forward. The fuel 


$$
\text { HNF-SD-SNF-TI-063, Rev. } 0
$$

Figure 9. Sketch of the Final Fuel Element Brush Assembly Used in 105-K West Basin. (A11 units are in inches unless otherwise specified.)
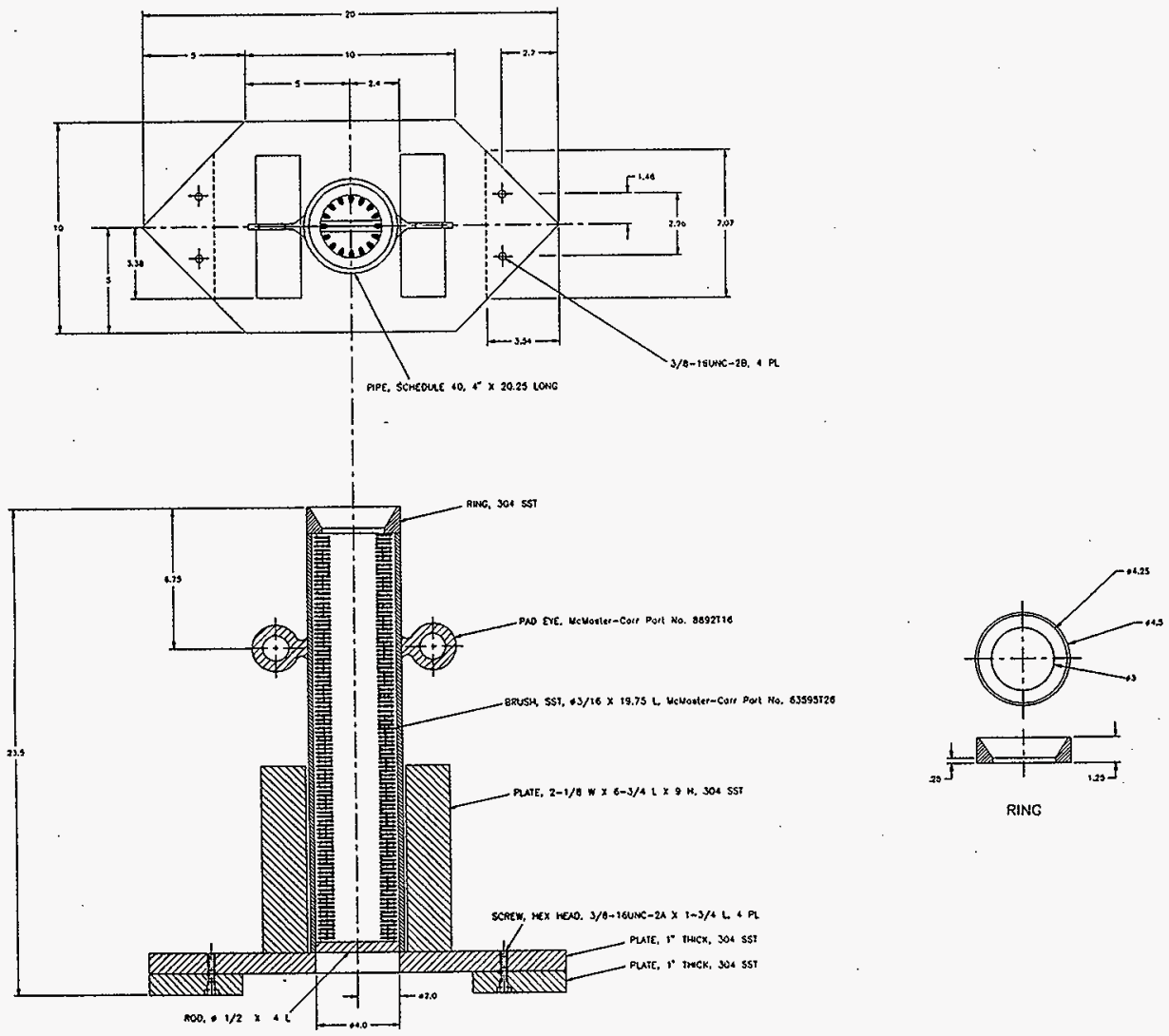
Figure 10. The Final Fuel Element Brush Assembly Used in 105-K West. The four pictures show the front, top, bottom, and side views of the Fuel Element Brush Assembiy.

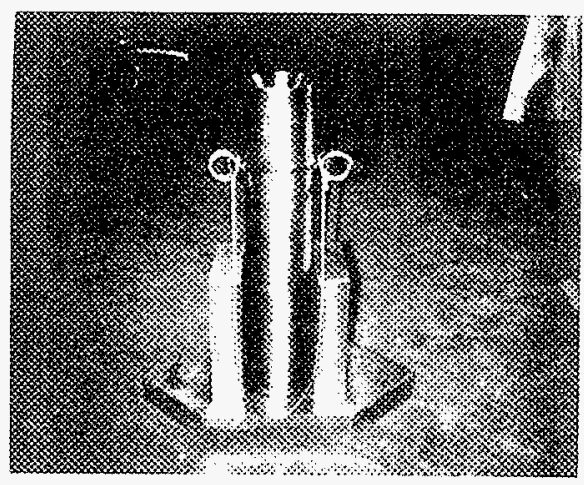

Front View

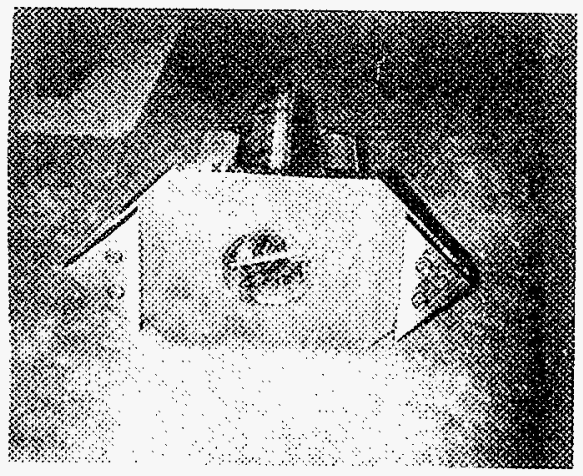

Bottom View

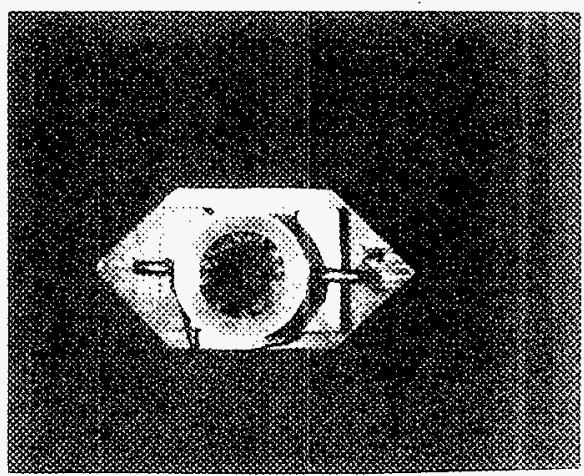

Top View

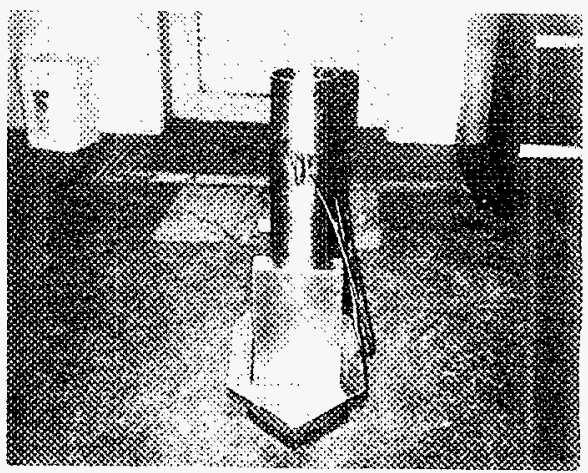

Side View 
element was placed into the FEBA and removed 13 more times. Each time the fuel element was removed from the FEBA, the FEBA slightly swayed forward. This demonstrated that the FEBAs bottom plate had the proper weight distribution to accomplish the sludge adherence testing. This was an important piece of information to know if there would be another FEBA built.

The rest of the FEBAs use is summarized here. The inclined ring worked very well when inserting the fuel element into the FEBA. It increased the cross sectional area, creating a bigger target to place the fuel element in the FEBA. The FEBA rocked back and forth in an apparent 20-degree arcing motion but never left the floor when the fuel elements were removed. The strokes of the fuel element were smooth with no jerking motion. This indicated that the fuel elements were not hard to remove from the FEBA, a fact confirmed by the operators. The FEBA seemed to do a very good job of removing the sludge coatings from the outside of the outer fuel elements (Maassen 1997). Only once was the FEBA pushed forward about 1 inch when a fuel element was removed from the FEBA. There was a minor loss of bristles from the brushes. Three bristles were identified as being removed from the FEBA; this constituted an insignificant number of bristles lost when compared to the total amount of bristles in the brushes.

The operators involved in the field use indicated that the FEBA was easy to use. Fuel elements were easily, inserted and removed. The swaying of the FEBA did not affect the operators performance when inserting or removing the fuel elements. The operators did not recommend any changes to the FEBA. Overa11, the FEBA worked very we11. 
HNF-SD-SNF-TI-063, Rev. 0

This page intentionally left blank. 


\subsection{CONCLUSION}

The project had some set backs from the beginning that led it to an extended schedule. The two major problems encountered during the project that were overcome were: (1) the lack of sketches from the first FEBA; and (2) the lack of clear communication between the individuals working on the project. The second problem was directly attributed to the need for a field modification of the FEBA, leading to a very aggressive schedule.

Even with these problems, the FEBA was a success in doing its job to test the adhesiveness of sludge coatings on the KW Basin outer fuel elements. While the FEBA was 2 days behind schedule, it did not affect the critical path of the overall testing in the KW Basin. The FEBA was built, successfully modified, and used without problems during the testing of the sludge coatings adhesiveness on fuel elements in the KW Basin. The only suggestions for building another FEBA would be: (1) to fit it more accurately inside the storage rack and (2) communication must be more clear and concise between the groups performing the work. 
HNF-SD-SNF-TI-063, Rev. 0

This page intentionally left blank. 


\subsection{REFERENCES}

Bergmann, D. W., and W. A. Briggs, 1996, S7udge Adherence Summary Report, WHC-SD-SNF-TRP-015, Rev. 0, Westinghouse Hanford Company, Richland, Washington.

Maassen, D. P., 1997, Testing of S7udge Coating Adhesiveness on Fuel Elements in 105-K West Basin, HNF-SD-SNF-TRP-020, Rev. 0, Duke Engineering \& Services Hanford, Inc., Richland, Washington.

Pitner, A. L., 1997, Visual Examinations of $K$ West Fuel Elements, HNF-SD-SNF-TI-046, Rev. 0, Duke Engineering \& Services Hanford, Inc., Richland, Washington.

PS-304-B3, Rev. 2, Process Standard "Fuel Decapping at 100-KW," December 1996.

Videotape \#221, 1997, "Fuel Element Brush Assembly \& Outer Element Hand1ing Tool Test/305 Building," Spent Nuclear Fuel Characterization Project Video Tape Inventory, Duke Engineering \& Services Hanford, Inc., Richl and, Washington. 


\section{DISTRIBUTION SHEET}

\begin{tabular}{|c|c|c|c|c|c|}
\hline \multirow{2}{*}{$\begin{array}{l}\text { To } \\
\text { Distribution }\end{array}$} & \multirow{2}{*}{\multicolumn{3}{|c|}{$\begin{array}{l}\text { From } \\
\text { SNF Characterization Project/ } \\
2 \mathrm{~T} 720\end{array}$}} & \multicolumn{2}{|l|}{ Page 1 of 1} \\
\hline & & & & \multicolumn{2}{|c|}{ Date October 8, 1997} \\
\hline \multicolumn{4}{|l|}{ Project Title/Work Order } & \multicolumn{2}{|c|}{ EDT No. 620795} \\
\hline \multicolumn{4}{|c|}{$\begin{array}{l}\text { Description of the Fuel Element Brush Assembly's Fabrication for } \\
105-K \text { West }\end{array}$} & \multicolumn{2}{|l|}{ ECN No. } \\
\hline Name & MSIN & $\begin{array}{l}\text { Text } \\
\text { With All } \\
\text { Attach. }\end{array}$ & Text Only & $\begin{array}{l}\text { Attach./ } \\
\text { Appendix } \\
\text { Only }\end{array}$ & $\begin{array}{l}\text { EDT/ECN } \\
\text { Only }\end{array}$ \\
\hline
\end{tabular}

Fluor Daniel Hanford
D. P. Maassen
(3)
HO- $40 \quad X$

Duke Engineering \& Services Hanford, Inc:

R. B. Baker

A. E. Bridges

W. A. Briggs

L. D. Bruggeman

S. A. Chastain

J. J. Jernberg

L. A. Lawrence

B. J. Makenas

P. J. MacFarlan

R. P. Omberg

A. L. Pitner

W. H. Rasin

D. J. Trimble

Central Files

SNF Project Files

Wastren

N. R. Roe
HO- 40

HO-40

R3-15

HO- 40

HO-40

$\mathrm{X} 3-72$

$\mathrm{HO}-40$

HO- 40

HO- 40

HO- 40

HO- 40

R3-11

HO- 40

A3-88

R3-11

$x$
$x$
$x$
$x$
$x$
$x$
$x$
$x$
$x$
$x$
$x$
$x$
$x$
$x$
$x$

HO-40 X 